\title{
Comparison of the Surgical Results for Foramen Magnum Decompression with and without Duraplasty in Chiari Malformation Type 1
}

\author{
Tip 1 Chiari Malformasyonlu Hastalarda Duraplastili ve Duraplastisiz \\ Foramen Magnum Dekompresyonunun Cerrabi Sonuçlarının \\ Karşılaştırılması
}

Mehmet Sabri GURBUZ ${ }^{1}$, Numan KARAASLAN ${ }^{2}$, Tezcan CALISKAN ${ }^{3}$, Emre UNAL ${ }^{1}$, Mehmet Zafer BERKMAN $^{4}$

${ }_{1}^{1}$ ğr State Hospital, Department of Neurosurgery, Agri, Turkey

${ }^{2}$ Namik Kemal University, School of Medicine, Department of Neurosurgery, Tekirdag, Turkey

${ }^{3}$ Gaziosmanpasa University, School of Medicine, Department of Neurosurgery, Tokat, Turkey

${ }^{4}$ Acibadem Maslak Hospital, Department of Neurosurgery, Istanbul, Turkey

Corresponding Author: Mehmet Sabri GURBUZ / E-mail: mehmetsabrigurbuz@gmail.com

\begin{abstract}
AIM: The surgical results for foramen magnum decompression (FMD) with and without duraplasty in Chiari Malformation type 1 (CM-1) were compared retrospectively.

MATERIAL and METHODS: Thirty-nine cases of CM-1 with and without syringomyelia (SM) were included. There were 18 patients in the nonduraplasty and 21 in the duraplasty group. Syringomyelia, tonsillar herniation (TH), preoperative symptom duration, and postoperative SM size were compared.

RESULTS: No significant difference was found between improvement in the duraplasty group (81\%) and the non-duraplasty group (61.1\%). In cases whose symptom duration was 0-36 months, improvement in the duraplasty group (93\%) was significantly better than in the nonduraplasty group $(50 \%)(p<0.01)$. The rate of syrinx regression was $92.3 \%$ in the duraplasty group and $12.5 \%$ in the non-duraplasty group $(p<0.05)$. In cases with $S M$, the improvement was $21.4 \%$ in the non-duraplasty group compared to $78.6 \%$ in the duraplasty group ( $p=0.056$ ). In cases with TH greater than $10 \mathrm{~mm}$, the improvement was $66.7 \%$ in the non-duraplasty group, whereas all six cases (100\%) in the duraplasty group had improved.
\end{abstract}

CONCLUSION: In SM associated cases, cases with TH greater than $10 \mathrm{~mm}$, and whose symptom duration is less than 36 months, duraplasty is a more reliable choice despite a slightly higher rate of complications.

KEYWORDS: Chiari malformation type 1, Syringomyelia, Duraplasty, Surgical results

öz

AMAÇ: Bu retrospektif çalışmada tip 1 Chiari Malformasyonlu (CM-1) hastalarda duraplastili ve duraplastisiz foramen magnum dekompresyonunun cerrahi sonuçları karşılaştırılmıştır.

YÖNTEM ve GEREÇLER: Sirengomyeli (SM) bulunan ve bulunmayan 39 CM-1 olgusu çalışmaya dahil edildi.duraplastisiz grupta 18, duraplastili grupta 21 olgu bulunmaktaydı. SM varlığı, tonsiler hernniasyon (TH) miktarı, preoperatif semptom süresi ve postoperatif SM boyutu karşılaştıııldı.

BULGULAR: Duraplastili $(\% 81)$ ve duraplastisiz grubun $(\% 61,1)$ iyileşme oranları arasında anlamlı fark bulunmadı. Preoperatif semptom süresi 0-36 ay arasında olan olgularda; duraplastili grubun iyileşme oranı (\%93) duraplastisiz gruba göre (\%50) anlamlı oranda yüksekti ( $p<0.05)$. Sirenks boyutunda küçülme oranı duraplastili grupta \% 92,3 iken duraplastisiz grupta \% $12.5 \mathrm{idi}(\mathrm{p}<0.05)$. SM bulunan olgularda; duraplastili grubun iyileşme oranı $\% 78,6$, duraplastisiz grubun iyileşme oranı ise $\% 21,4$ idi ( $p=0.056$ ). TH'un 10 mm'den fazla olduğu olgularda; duraplastisiz grubun iyileşme oranı \% 66,7 iken, duraplastili 6 olgunun tamamı iyileşmişti (\%100).

SONUÇ: SM'li olgularda, TH'un 10 mm'den fazla olduğu olgularda ve semptom süresi 36 aydan kısa olan olgularda duraplasti hafif yüksek komplikasyon oranı olmakla birlikte daha iyi bir seçenek olarak düşünülmüştür.

ANAHTAR SÖZCÜKLER:Tip 1 Chiari malformasyonu, Sirengomyeli, Duraplasti, Cerrahi sonuçlar 


\section{INTRODUCTION}

Chiari Malformation type 1 (CM-1) is defined as the downward displacement of the cerebellar tonsils and medial portions of the inferior cerebellar lobules through the foramen magnum into the upper cervical spinal canal. Obstruction of cerebrospinal fluid (CSF) at the level of the foramen magnum and thus altered CSF dynamics result in syringomyelia. CM-1 patients present with findings of either syringomyelia or brainstem compression $(9,25)$.

In 1883, John Cleland (29) described deformities of the brainstem, cerebellum, spina bifida and medullary cavitation. In 1891, Hans Chiari described three types of anomaly of the craniovertebral junction based on a few cases, and in 1895, described the three types and added a fourth type based on a higher number of cases $(9,29)$. In 1998, Iskandar et al. (12) described 'Chiari Zero malformation' to characterize a type of syringomyelia that exhibits classical CM-1 symptoms with little to no herniation. In 2010, Kim et al. described 'Chiari 1.5 malformation' as an advanced form of CM-1 (14).

Despite the fact that many theories have increased our knowledge about Chiari malformation (CM), the exact pathogenesis is still unclear (18). In 1943, Lichtenstein (16) was the first to mention the theory of a small posterior fossa and he pointed out that the reason for the downward displacement of the rhombencephalon is an underdeveloped posterior fossa. In 1978, Nyland and Krogness (23) reported a small posterior fossa in five cases of $\mathrm{CM}$. The most accepted theory has been this 'theory of a small posterior fossa' $(4,20)$. After measurement of posterior fossa parameters, Nishikawa et al. revealed that an underdeveloped occipital bone induces overcrowding in the posterior cranial fossa, which contains the normally developed hindbrain in adult-type CM (22).

There is no consensus on the surgical treatment of $\mathrm{CM}-1$ (25). Despite the fact that many different treatment modalities have been studied and proposed, there are two main modalities available. One of these is posterior fossa decompression with or without duraplasty to increase the posterior fossa volume and the other is different shunt procedures to reduce the cavity of syringomyelia (SM) (18). Some authors have advocated that posterior fossa decompression without duraplasty [suboccipital craniectomy, C1 (first cervical vertebra) laminectomy and C2 (second cervical vertebra) laminectomy when needed] is sufficient $(9,13,26,31)$, whereas others have advocated duraplasty $(6-8,25,27)$. In this study, we compared the surgical results for posterior fossa decompression with and without duraplasty in the light of the current literature.

\section{MATERIAL and METHODS}

From 2005 to 2012, 45 cases suffering from CM-1 with and without syringomyelia (SM) were operated at our institute. In total, 39 met our criteria and were analysed retrospectively. Cases were identified from the hospital medical archive from epidemiological information, clinical presentation, radiological findings, and the condition of the patients at discharge and at follow-up.
As in the literature, the following patients were excluded: those who were under 15 years of age, patients with other types of CM, patients with other associated malformations such as basilar invagination or other craniovertebral anomalies, and patients who had been treated with other methods such as syringosubarachnoid shunt (25). Indications for surgery were progressive disabling symptoms (Table I), in addition to radiological diagnosis. The first group was the non-duraplasty group (posterior fossa decompression only) consisting of 18 patients, and the second group was the duraplasty group (posterior fossa decompression and duraplasty) consisting of 21 patients. All patients underwent a decompressive suboccipital craniectomy extending at least $3 \mathrm{~cm}$ above the foramen magnum with a width of at least 4 $\mathrm{cm}$, and total $\mathrm{C} 1$ laminectomy was performed as described in the literature $(5,9,29,31)$.

Yılmaz et al. (30) classified the amount of tonsillar herniation (TH) according to the spatial relationship between the herniated tonsils and the posterior arch of $\mathrm{C} 1$. As a simpler method, we classified the TH according to the length $(\mathrm{mm})$ of tonsillar descent from the foramen magnum as either $5-10 \mathrm{~mm}$ or $10-20 \mathrm{~mm}$. The preoperative symptom duration was divided into two groups as either $0-36$ months or 36120 months. The presence of SM and postoperative state of the syringomyelia cavity were taken into consideration. Postoperative states of the patients were classified as 'same and stabilized', 'improved' or 'worsened' as suggested in the literature (31).

\section{RESULTS}

The ages of the patients ranged from 15 to 59 with a mean age of 36 . The follow-up period was between 5 and 75 months with a mean of 43 months; $33.3 \%(n=13)$ of the patients were male and $66.7 \%(n=26)$ were female. Preoperative symptom duration was $0-36$ months $(n=25)$ in $64.1 \%$ and $36-120$ months $(n=14)$ in $35.9 \%$ of the patients. Preoperative

Table I: Preoperative Signs Symptoms

\begin{tabular}{|l|r|r|}
\hline Head-neck pain & $\mathbf{n}$ & $\%$ \\
\hline Vertigo & 29 & 74.4 \\
\hline Numbness & 1 & 2.6 \\
\hline Drop attack & 27 & 69.2 \\
\hline Gait disturbance & 1 & 2.6 \\
\hline Imbalance & 5 & 12.8 \\
\hline Cranial nerve problems & 6 & 15.4 \\
\hline Cerebellar symptoms & 3 & 7.7 \\
\hline Motor deficit & 6 & 15.4 \\
\hline Extremity pain & 13 & 33.3 \\
\hline Hearing abnormality & 5 & 12.8 \\
\hline Impairment of temperature sensation & 1 & 2.6 \\
\hline Hyperreflexia & 11 & 28.2 \\
\hline Pathological reflex & 10 & 25.6 \\
\hline
\end{tabular}


symptoms were the same as in the literature (Table I). TH was $5-10 \mathrm{~mm}$ in $61.5 \%(\mathrm{n}=24)$ and $10-20 \mathrm{~mm}$ in $38.5 \%(\mathrm{n}=15)$ of the patients. SM was associated with $53.8 \%(n=21)$ of the patients.

In our study, foramen magnum decompression (FMD) alone was performed in 18 patients (non-duraplasty group), and FMD with duraplasty was performed in 21 patients (duraplasty group). No statistically significant difference was found between the surgical results for FMD with and without duraplasty. The rate of improvement was $37.5 \%$ in patients whose syrinx cavity size did not decrease and $84.6 \%$ in patients whose syrinx cavity size decreased postoperatively. The rate of postoperative syrinx regression was significantly higher in the duraplasty group (92.3\%) than in the non- duraplasty group $(12.5 \%)(\mathrm{p}<0.01)$ (Table II). Improvement was seen in 11 out of 13 (84.6\%) cases with SM, and 3 out of 8 (37.5\%) cases without SM (Table III). The rate of patients who remained unchanged was $15.4 \%$ in the duraplasty group and $62.5 \%$ in the non-duraplasty group.

Among the patients whose preoperative symptom duration was 36-120 months, no significant difference was found between the rate of improvement in the duraplasty and non-duraplasty groups. However, among the cases whose preoperative symptom duration was 0-36 months, the rate of improvement was $93 \%$ in the duraplasty group and $50 \%$ in the non-duraplasty group $(\mathrm{p}<0.05)$ (Table III).

Among the patients whose $\mathrm{TH}$ was $5-10 \mathrm{~mm}$, no significant difference was found between the rate of improvement in

Table II: The Relationship Between the Postoperative Syrinx Size and the Surgical Technique

\begin{tabular}{|c|c|c|c|c|}
\hline & & Surgice & ique & \\
\hline & & Non-duraplasty & Duraplasty & $\mathbf{p}$ \\
\hline & & $n(\%)$ & $n(\%)$ & \\
\hline & & $(n=8)$ & $(n=13)$ & \\
\hline Postoperative syrinx size & $\begin{array}{l}\text { Unchanged } \\
\text { Regressed }\end{array}$ & $\begin{array}{l}7(87.5 \%) \\
1(12.5 \%)\end{array}$ & $\begin{array}{c}1(7.7 \%) \\
12(92.3 \%)\end{array}$ & $0.001 * *$ \\
\hline
\end{tabular}

Fisher's Exact Test, ${ }^{* *} p<0.01$

Table III: The Relationship Between the Surgical Technique and Presence of SM, Preoperative Symptom Duration and the Amount of Tonsillar Herniation

\begin{tabular}{|c|c|c|c|c|}
\hline & & \multicolumn{2}{|c|}{ Surgical technique } & \multirow{3}{*}{$\mathbf{p}$} \\
\hline & & Non-duraplasty & Duraplasty & \\
\hline & & n (\%) & $n(\%)$ & \\
\hline \multicolumn{2}{|c|}{ Not associated with SM } & $(n=10)$ & $(n=8)$ & \\
\hline Surgical result & $\begin{array}{l}\text { Unchanged } \\
\text { Improved }\end{array}$ & $\begin{array}{l}2(20.0 \%) \\
8(80.0 \%)\end{array}$ & $\begin{array}{l}2(25.0 \%) \\
6(75.0 \%)\end{array}$ & 1.000 \\
\hline \multicolumn{2}{|c|}{ Associated with SM } & $(n=8)$ & $(n=13)$ & \\
\hline Surgical result & $\begin{array}{l}\text { Unchanged } \\
\text { Improved }\end{array}$ & $\begin{array}{l}5(62.5 \%) \\
3(37.5 \%)\end{array}$ & $\begin{array}{r}2(15.4 \%) \\
11(84.6 \%)\end{array}$ & 0.056 \\
\hline \multicolumn{2}{|c|}{ 0-36 months of symptom duration } & $(n=10)$ & $(n=15)$ & \\
\hline Surgical result & $\begin{array}{l}\text { Unchanged } \\
\text { Improved }\end{array}$ & $\begin{array}{l}5(50.0 \%) \\
5(50.0 \%)\end{array}$ & $\begin{array}{c}1(6.7 \%) \\
14(93.3 \%)\end{array}$ & $0.023 *$ \\
\hline \multicolumn{2}{|c|}{ 36-120 months of symptom duration } & $(n=8)$ & $(n=6)$ & \\
\hline Surgical result & $\begin{array}{l}\text { Unchanged } \\
\text { Improved }\end{array}$ & $\begin{array}{l}2(25.0 \%) \\
6(75.0 \%)\end{array}$ & $\begin{array}{l}3(50.0 \%) \\
3(50.0 \%)\end{array}$ & 0.580 \\
\hline \multicolumn{2}{|c|}{ Tonsillar herniation 5-10 mm } & $(n=9)$ & $(n=15)$ & \\
\hline Surgical result & $\begin{array}{l}\text { Unchanged } \\
\text { Improved }\end{array}$ & $\begin{array}{l}4(44.4 \%) \\
5(55.6 \%)\end{array}$ & $\begin{array}{r}4(26.7 \%) \\
11(73.3 \%)\end{array}$ & 0.412 \\
\hline \multicolumn{2}{|c|}{ Tonsillar herniation of $10-20 \mathrm{~mm}$} & $(n=9)$ & $(n=6)$ & \\
\hline Surgical result & $\begin{array}{l}\text { Unchanged } \\
\text { Improved }\end{array}$ & $\begin{array}{l}3(33.3 \%) \\
6(66.7 \%)\end{array}$ & $\begin{array}{l}0(0.0 \%) \\
6(100.0 \%)\end{array}$ & 0.229 \\
\hline
\end{tabular}

Fisher's Exact Test, * $p<0.05$ 
the duraplasty and non-duraplasty groups. However, among the cases whose TH was $10-20 \mathrm{~mm}$, the rate of improvement was $66.7 \%$ in the non-duraplasty group, whereas all six cases $(100 \%)$ in the duraplasty group improved (Table III).

Postoperative infection was seen in $5.6 \%$ of the nonduraplasty group and $19 \%$ of the duraplasty group. The rate of reoperation was $14.3 \%$ in the duraplasty group and $22.2 \%$ in the non-duraplasty group. Two cases of postoperative CSF fistula and one case of pseudomeningocele occurred in the duraplasty group. The overall complication rate was $5.6 \%$ in the non-duraplasty group and $28.6 \%$ in the duraplasty group which is slightly higher but not statistically significant.

\section{DISCUSSION}

CM-1 constitutes a group of entities of congenital or acquired aetiology that have, in common, descent of the cerebellar tonsils into the cervical spinal canal $(3,25)$. It is associated with syringomyelia in $30-70 \%$ of cases $(1,10)$. Diagnosis of CM-1 is made based on both clinical and radiological findings (29). Clinical signs result either from compression of neural structures at the craniovertebral junction or from the cavity of SM $(25,28)$.

Preoperative symptom duration is invariably long in $\mathrm{CM}-1$ since it is a slowly progressive disease $(7,8)$. Mean preoperative symptom duration was 7.6 years in the series studied by Matsumoto and Symon (19), 6.2 years in the series reported by Arruda et al. (1) and 5.4 years in the series studied by Dyste and Menezes (8). The preoperative symptom duration was $0-36$ months in $64.1 \%$ of our patients and $36-120$ months in $35.9 \%$ of our patients. In the series reported by Ramnarayan et al., when the duration of illness was less than 5 years, the rate of improvement increased (25). However, there are no data available in the literature mentioning the relationship between preoperative symptom duration and the success of the surgical technique in $\mathrm{CM}-1$. In our series, among the patients whose preoperative symptom duration was 0-36 months, the rate of improvement was $93 \%$ in the duraplasty group whereas it was $50 \%$ in the non-duraplasty group, which is statistically significant $(p<0.05)$. No significant difference was found between the duraplasty and non-duraplasty groups among the patients with preoperative symptom duration of 36-120 months.

Despite the fact that many different treatment modalities have been studied, two types of surgical procedure have generally been proposed. One of these is posterior fossa decompression with or without duraplasty to increase the posterior fossa volume, and the other is to use different types of shunt procedure to reduce the size of the syrinx cavity (18). Some authors $(9,13,26,31)$ have advocated that posterior fossa decompression without duraplasty is sufficiently effective, whereas others $(6-8,25,27)$ have suggested adding duraplasty. Since shunt procedures have a potential risk of iatrogenic spinal cord injury, posterior fossa decompression with or without duraplasty remains the primary surgical technique whereas shunt surgeries are accepted as complementary surgical procedures $(5,6,11)$.
James and Brant suggested FMD without durotomy as an effective treatment modality in children and teenagers (13). Erdogan et al. reported that the symptoms and signs had resolved in $83 \%$ of their patients after FMD without duraplasty but the rate of syrinx regression was only $28 \%$ (9). In another study including FMD without durotomy, 'very good' results were achieved in $66 \%$ of patients with 'good' results in $26 \%$ (31). Romero et al. reported that four out of six cases undergoing FMD without duraplasty had improved (26). In the series reported by Yilmaz et al, 24 out of 58 patients underwent FMD without duraplasty and clinical improvement was seen in $79.1 \%$ of the patients (30). Several groups have suggested that duraplasty is absolutely necessary and without it, tissue scarring and recurrence rates increase (6-8). Sindou et al. suggested opening of the dura with preservation of the arachnoid membrane and adding duraplasty, and reported favourable results (27). Improvement was seen in 20 out of 23 patients in the series reported by Ramnarayan et al. (25). In that series, 8 out of 11 patients benefited from posterior fossa decompression but the syrinx cavity regressed in only $50 \%$ of the patients. On the other hand, in the duraplasty group, 20 out of 23 patients improved and the syrinx cavity regressed in all of them (25). Klekamp reported postoperative improvement after 3 months as $82 \%$ of 359 patients having undergone posterior fossa decompression, arachnoid dissection, and an alloplastic duraplasty (15). In the duraplasty group in our study, $81 \%$ of the patients improved and 19\% remained unchanged and stabilized, and none of them worsened. In the non-duraplasty group, 11 of 18 patients improved (61\%) and the remaining seven patients $(39 \%)$ remained unchanged or stabilized and none of them worsened. Taking all cases into consideration, no statistically significant difference was found between the surgical results for FMD with and without duraplasty.

Romero et al. reported that four out of six patients improved in the non-duraplasty group and nine out of 10 patients improved in the duraplasty group concluding that duraplasty is effective in cases with associated syringomyelia (26). Matsumoto and Symon found no significant difference between regression rates for the syrinx cavity in their duraplasty and non-duraplasty groups (19). Munshi et al. pointed out that surgical results are significantly worse with the non-duraplasty technique (21). Romero and Pereira reported that the syrinx regressed in all of five patients with syringomyelia who underwent duraplasty concluding that duraplasty is more effective in cases with associated syringomyelia (26). In our series, the syrinx cavity regressed in $92.3 \%$ of the duraplasty group compared to $12.5 \%$ in the nonduraplasty group which is statistically significant $(p<0.01)$. On the other hand, the rate of improvement was $37.5 \%$ in patients whose syrinx remained unchanged and $84.6 \%$ in patients whose syrinx regressed $(p=0.056)$. In cases with associated $\mathrm{SM}$, the rate of improvement was $21.4 \%$ in the non-duraplasty group compared to $78.6 \%$ in the duraplasty group $(p=0.056$ ). In cases without SM, no difference was found between the duraplasty and non-duraplasty groups. In cases with SM, 
$15.4 \%$ remained unchanged in the duraplasty group whereas $62.5 \%$ remained unchanged in the non-duraplasty group.

Yilmaz et al. classified cerebellar tonsillar descent (CTD) as grade I (the tonsil descended more than $5 \mathrm{~mm}$ below the foramen magnum but did not reach the $\mathrm{C} 1 \mathrm{arch}$ ), grade II (the tonsil reached the $\mathrm{C} 1 \mathrm{arch}$ ) and grade III (the tonsil descended below the $\mathrm{C} 1 \mathrm{arch}$ ) (30). There were no statistically significant differences between preoperative and postoperative size of the syrinx cavity and rate of improvement in the duraplasty and non-duraplasty groups in CTD grade I and II, but in CTD grade III, the decrease in size of the syrinx cavity and clinical improvement were statistically significantly better in the duraplasty group. In our study, there was no statistically significant difference between the duraplasty and nonduraplasty groups with $\mathrm{TH}$ of $5-10 \mathrm{~mm}$, however with $\mathrm{TH}$ of $10-20 \mathrm{~mm}$, the rate of improvement was $66.7 \%$ (6 out of 9 patients) in the non-duraplasty group compared to $100 \%$ (all of six cases) improvement in the duraplasty group ( $p>0.05)$.

The complication rate was slightly higher in the duraplasty group than in the non-duraplasty group (9). Parker et al. reported a $21.1 \%$ complication rate in their retrospective study including 114 patients in the duraplasty group, and in their series, the most frequent complications were aseptic meningitis, symptomatic pseudomeningocele and CSF fistula (24). Klekamp reported a $21.8 \%$ complication rate in a retrospective study including 359 patients in the duraplasty group (15). In the series reported by Hida et al., postoperative meningitis was seen in two and kyphosis in one out of 33 patients in the non-duraplasty group (11). Arruda et al. reported $23 \%$ pseudomeningocele and $6.6 \%$ meningitis in their series including 60 patients in the duraplasty group (1). In our study, the rate of complication was $20.5 \%$ which is in line with the literature. CSF fistula was seen in $5.1 \%$ of patients, meningitis in $12.8 \%$ of patients and pseudomeningocele in $2.6 \%$ of patients. The postoperative complication rate was $5.6 \%$ in the non-duraplasty group and $28.6 \%$ in the duraplasty group which is consistent with the literature. There were no statistically significant differences between the reoperation rates in the two groups. Seven cases needed reoperation, four of which were from the non-duraplasty group and three from the duraplasty group. In three patients in the non-duraplasty group, preoperative complaints recurred in the postoperative period and additional duraplasty operations were carried out. In one patient, the syrinx size increased again 3 months after surgery and a syringopleural shunt operation was performed. In the duraplasty group, two patients were operated for enlargement of the duraplasty and one patient had an additional C2 laminectomy.

The mortality rate was $3.1 \%$ in the series reported by Matsumoto and Symon (19) and $1.3 \%$ in the series reported by Logue and Edwards (17). Bindal et al. and Arruda et al. reported no mortality in their series $(1,2)$. No mortality was seen in our study.

\section{CONCLUSIONS}

No statistically significant difference was found between the surgical results for FMD with or without duraplasty. However, in cases with associated SM, whose TH was greater than 10 $\mathrm{mm}$ and whose symptom duration was less than 36 months, duraplasty may be considered to be a more reliable choice despite a slightly higher rate of complications. However, these conclusions need to be verified in studies with larger series.

\section{REFERENCES}

1. Arruda JA, Costa CM, Tella Jr Ol: Results of the treatment of syringomyelia associated with chiari malformation: Analysis of 60 cases. Arq Neuropsiquiatr 62:237-244, 2004

2. Bindal AK, Dunsker SB, Tew JM Jr: Chiari I malformation: Classification and management. Neurosurgery 37:10691074, 1995

3. Cahan LD, Bentson JR: Considerations in the diagnosis and treatment of syringomyelia and the Chiari malformation. J Neurosurg 57:24-31, 1982

4. Chou YC, Sarkar R, Osuagwu FC, Lazareff JA: Suboccipital craniotomy in the surgical treatment of Chiari I malformation. Childs Nerv Syst 25:1111-1114, 2009

5. da Silva JA, dos Santos AA Jr, Melo LR, de Araújo AF, Regueira GP: Posterior fossa decompression with tonsillectomy in 104 cases of basilar impression, Chiari malformation and/or syringomyelia. Arq Neuropsiquiatr 69(5):817-823, 2011

6. Di Lorenzo N, Palma L, Palatinsky E, Fortuna A: “Conservative” cranio-cervical decompression in the treatment of syringomyelia-Chiari I complex. A prospective study of 20 adult cases. Spine 20:2479-2483, 1995

7. Dyste GN, Menezes AH: Presentation and management of pediatric Chiari malformations without myelodysplasia. Neurosurgery 23:589-597, 1988

8. Dyste GN, Menezes AH, VanGilder JC: Symptomatic Chiari malformations. An analysis of presentation, management, and long-term outcome. J Neurosurg 71:159-168, 1989

9. Erdogan E, Cansever T, Secer HI, Temiz C, Sirin S, Kabatas $\mathrm{S}$, Gonul E: The evaluation of surgical treatment options in the Chiari Malformation Type I. Turk Neurosurg 20(3):303313, 2010

10. Goel A, Desai K: Surgery for syringomyelia: an analysis based on 163 surgical cases. Acta Neurochir (Wien) 142:293-301, 2000

11. Hida K, Iwasaki Y, Koyanagi I, Sawamura Y, Abe H: Surgical indication and results of foremen magnum decompression versus syringosubarachnoid shunting for syringomyelia associated with Chiari I malformation. Neurosurgery 37:673-678, 1995

12. Iskandar BJ, Hedlund GL, Grabb PA, Oakes WJ: The resolution of syringohydromyelia without hindbrain herniation after posterior fossa decompression. J Neurosurg 89:212-216, 1998

13. James $H E$, Brant A: Treatment of the Chiari malformation with bone decompression without durotomy in children and young adults. Childs Nerv Syst 18:202-206, 2002 
14. Kim IK, Wang KC, Kim IO, Cho BK: Chiari 1.5 malformation: An advanced form of Chiari I malformation. J Korean Neurosurg Soc 48:375-379, 2010

15. Klekamp J: Surgical treatment of Chiari I malformation - analysis of intraoperative findings, complications, and outcome for 371 foramen magnum decompressions. Neurosurgery 71:365-380, 2012

16. Lichtenstein BW: Cervical syringomyelia and syringomyelialike states associated with Arnold-Chiari deformity and platybasia. Arch Neurol Psychiatry 49:881-894, 1943

17. Logue V, Edwards MR: Syringomyelia and its surgical treatment - an analysis of 75 patients. J Neurol Neurosurg Psychiatry 44:273-284, 1981

18. Ma J, You C, Chen H, Huang S, leong C: Cerebellar tonsillectomy with suboccipital decompression and duraplasty by small incision for Chiari I malformation (with syringomyelia): Long term follow-up of 76 surgically treated cases. Turk Neurosurg 22:274-279, 2012

19. Matsumoto T, Symon L: Surgical management of syringomyelia - current results. Surg Neurol 32:258-265, 1989

20. Milhorat TH, Nishikawa M, Kula RW, Dlugacz YD: Mechanisms of cerebellar tonsil herniation in patients with chiari malformations as guide to clinical management. Acta Neurochir (Wien) 152:1117-1127, 2010

21. Munshi I, Frim D, Stine-Reyes R, Weir BK, Hekmatpanah J, Brown F: Effects of posterior fossa decompression with and without duraplasty on Chiari malformation-associated hydromyelia. Neurosurgery 46:1384-1389, 2000

22. Nishikawa $M$, Sakamoto $H$, Hakuba A, Nakanishi $N$, Inoue $Y$ : Pathogenesis of Chiari malformation: A morphometric study of the posterior cranial fossa. J Neurosurg 86:40-47, 1997

23. Nyland H, Krogness KG: Size of posterior fossa in Chiari type 1 malformation in adults. Acta Neurochir (Wien) 40:233-242, 1978
24. Parker SR, Harris P, Cummings TJ, George T, Fuchs H, Grant $\mathrm{G}$ : Complications following decompression of chiari malformation type 1 in children: Dural graft or sealant? J Neurosurg Pediatr 8:177-183, 2011

25. Ramnarayan R, Praharaj MS, Jayakumar PN: Chiari 1 malformations: An Indian hospital experience. Singapore Med J 49:1029-1034, 2008

26. Romero FR, Pereira CA: Suboccipital craniectomy with or without duraplasty: what is the best choice in patients with Chiari type 1 malformation? Arq Neuropsiquiatr 68(4):623626,2010

27. Sindou M, Chávez-Machuca J, Hashish H: Cranio-cervical decompression for Chiari type I-malformation, adding extreme lateral foramen magnum opening and expansile duroplasty with arachnoid preservation. Technique and long-term functional results in 44 consecutive adult cases - comparison with literature data. Acta Neurochir (Wien) 144:1005-1019, 2002

28. Steinbok P: Clinical features of Chiari I malformations. Childs Nerv Syst 20:329-331, 2004

29. Taricco MA, Melo LR: Retrospective study of patients with Chiari: Malformation submitted to surgical treatment. Arq Neuropsiquiatr 66:184-188, 2008

30. Yilmaz A, Kanat A, Musluman AM, Colak I, Terzi Y, Kayacı $S$, Aydin $Y$ : When is duraplasty required in the surgical treatment of Chiari malformation type I based on tonsillar descending grading scale? World Neurosurg 75:307-313, 2011

31. Zhou DB, Zhao JZ, Zhang D, Zhao YL: Suboccipital bony decompression combined with removal of the dural band as treatment for Chiari I malformation. Chin Med J (Engl) 117:1274-1277, 2004 